\title{
METHOD DEVELOPMENT AND VALIDATION FOR SIMULTANEOUS ESTIMATION OF LAMIVUDINE AND ZIDOVUDINE IN TABLET BY REVERSE-PHASE HIGH-PERFORMANCE LIQUID CHROMATOGRAPHY
}

\author{
BHOOMI D PATEL*, MEHTA BHAVYA, ANKIT B CHAUDHARY
} Department of Quality Assurance, Saraswati Institute of Pharmaceutical Sciences, Dhanap, Gandhinagar, Gujarat, India.
Email: bhoomipatel2512@gmail.com

Received: 27 February 2020, Revised and Accepted: 05 April 2020

\section{ABSTRACT}

Objective: The objective of the study was to develop and validate reverse-phase high-performance liquid chromatography (RP-HPLC) method and apply method to tablet dosage form.

Methods: A simple, rapid, economical, precise, and accurate RP-HPLC method for simultaneous estimation of lamivudine and zidovudine in their combined dosage form has been developed.

Results: A RP-HPLC method was developed for the simultaneous estimation of lamivudine and zidovudine. In their combined dosage form has been developed. The separation was achieved by LC-C $\mathrm{C}_{18}$ column $(150 \mathrm{~mm} \times 4.6 \mathrm{~mm}, 5 \mu \mathrm{m})$ and water: methanol $(65: 35 \mathrm{v} / \mathrm{v})$ as mobile phase, at a flow rate of $0.8 \mathrm{ml} / \mathrm{min}$. Detection was carried out at $272 \mathrm{~nm}$. Retention time of lamivudine and zidovudine was found to be $3.007 \mathrm{~min}$ and 4.647 , respectively. The method has been validated for linearity, accuracy, and precision. The assay method was found to be linear from $50 \%$ to $150 \%$ for lamivudine and zidovudine.

Conclusion: Developed method was found to be accurate, precise, and rapid for simultaneous estimation of lamivudine and zidovudine in their combined dosage form.

Keywords: Infrared spectroscopy method, Lamivudine and zidovudine, Reverse-phase high-performance liquid chromatography method, Validation.

(C) 2020 The Authors. Published by Innovare Academic Sciences Pvt Ltd. This is an open access article under the CC BY license (http://creativecommons. org/licenses/by/4. 0/) DOI: http://dx.doi.org/10.22159/ajpcr.2020.v13i6.37288

\section{INTRODUCTION}

Lamivudine designated chemically as 4-Amino-1-[(2R,5S)-2(hydroxymethyl)-1,3-oxathiolan-5-yl]-1,2-dihydropyrimidin-2-one (Fig. 1) is a compound of the pyrimidine class and is used as antiviral agent $[1,2]$. It acts by inhibiting the HIV reverse transcriptase as well as hepatitis B virus. Its incorporation into DNA results in chain termination. Most human DNA polymerases are not affected and systemic toxicity of lamivudine is low. Various analytical methods have been reported for the estimation of lamivudine as alone as well as in combination with other drugs. They include thin-layer chromatography (TLC) [3], high-performance liquid chromatography (HPLC) [4], and reverse-phase (RP)-HPLC methods with other drugs [4-6].

\section{Zidovudine designated chemically as} 1-[(2R,4S,5S)-4-Azido-5-(hydroxymethyl)oxolan-2-yl]-5-methylpyri midine-2,4-dion (Fig. 2) is a compound of pyrimidine class and is used as antiviral [1,7,8]. Zidovudine (prototype of NRTI) is a thymidine analog. After phosphorylation in host cell, zidovudine triphosphate selectively inhibits viral reverse transcriptase (RNA-dependent DNA polymerase) in the presence of cellular DNA polymerase. It prevents conversion of single-stranded viral RNA to double-stranded viral DNA. They include TLC $[9,10]$, RP-HPLC [9], and RP-HPLC methods with other drugs [11-13]. However, an extensive literature search did not reveal any estimation method for both the drugs in their combined dosage form. Therefore, attempt was made to develop and validate simple, precise, and accurate, stability-indicating RP-HPLC method for simultaneous determination of both the drugs in their combined dosage form. The guideline on drug analytical method validation FDA [14].

\section{METHODS}

\section{Reagents and Chemicals}

Lamivudine and zidovudine were obtained as gift samples from Cipla Pharmaceuticals Ltd., combined dosage form tablet was purchased from local market. HPLC grade water and methanol of analytical grade were obtained from SD Fine Chem Ltd.

\section{Instruments and chromatographic conditions}

Young Lin HPLC system was used for method development, degradation studies, and validation. Data acquisition was performed on YL 9100 HPLC software. The separation was achieved on $\mathrm{C}_{18}$ column $(150 \mathrm{~mm}$ $\times 4.6 \mathrm{~mm}, 5 \mu \mathrm{m})$. The column was maintained at room temperature and the eluent was monitored at $272 \mathrm{~nm}$ using PDA detector. The mixture of water: methanol $(65: 35 \mathrm{v} / \mathrm{v})$ at a flow rate of $0.8 \mathrm{ml} / \mathrm{min}$ was used as a mobile phase. The injection volume was $20 \mu \mathrm{l}$.

\section{Preparation of solutions}

Preparation of lamivudine standard stock solutions $(100 \mu \mathrm{g} / \mathrm{ml})$

Weigh accurately $10 \mathrm{mg}$ of lamivudine and transfer it to $100 \mathrm{ml}$ volumetric flask. Add $50 \mathrm{ml}$ of methanol, shake well to dissolve and dilute up to the mark with methanol, and mix them thoroughly.

Preparation of zidovudine standard stock solutions $(250 \mu \mathrm{g} / \mathrm{ml})$

Weigh accurately $25 \mathrm{mg}$ of zidovudine and transfer it to $100 \mathrm{ml}$ volumetric flask. Add $50 \mathrm{ml}$ of methanol, shake well to dissolve and dilute up to the mark with methanol, and mix them thoroughly.

Working standard solution of lamivudine and zidovudine $(10: 25 \mu \mathrm{g} / \mathrm{ml})$ Pipette out $1 \mathrm{ml}$ of lamivudine standard stock solution and $1 \mathrm{ml}$ of zidovudine standard stock solution into $10 \mathrm{ml}$ volumetric flask and dilute up to the mark with diluents and mixed thoroughly. 
Preparation of mobile phase

Accurately measure $650 \mathrm{ml}$ of $0.1 \%$ TFA in HPLC grade $\mathrm{H}_{2} \mathrm{O}$ and $350 \mathrm{ml}$ of methanol, mix thoroughly and degassed by sonication to make $65: 35 \% \mathrm{v} / \mathrm{v}$

\section{System suitability parameters}

System suitability tests were performed to verify that the resolution and repeatability of the system were adequate for the analysis intended. The parameters monitored for system suitability include retention time, theoretical plate number, peak area, tailing factor, and resolution. The repeatability of these parameters was checked by injecting 3 times the test solution of lamivudine $10 \mu \mathrm{g} / \mathrm{mL}$ and zidovudine $25 \mu \mathrm{g} / \mathrm{mL}$. The results shown in Table 1 were within acceptable limits.

\section{Method validation}

Specificity

Specificity of method can be termed as absence of any interference at retention times of samples. Specificity was performed by injecting

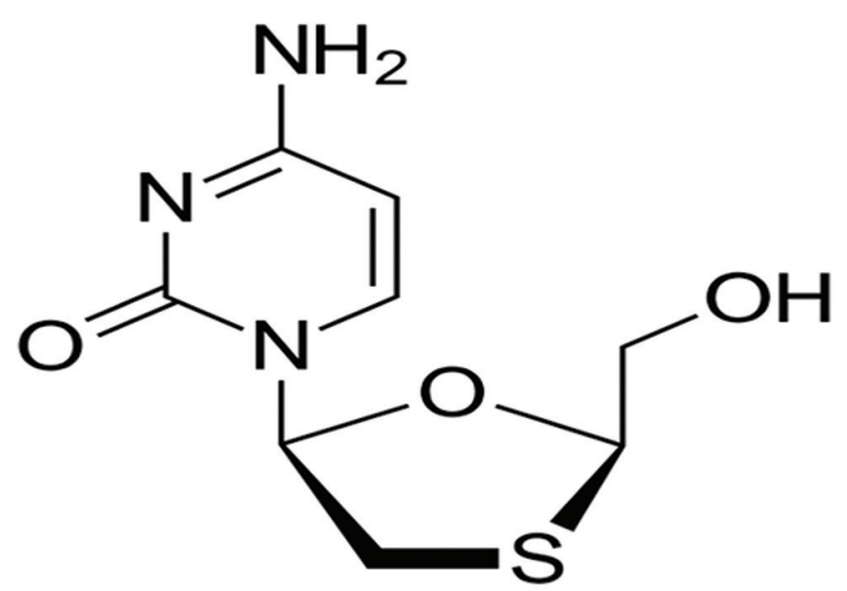

Fig. 1: Chemical structure of lamivudine

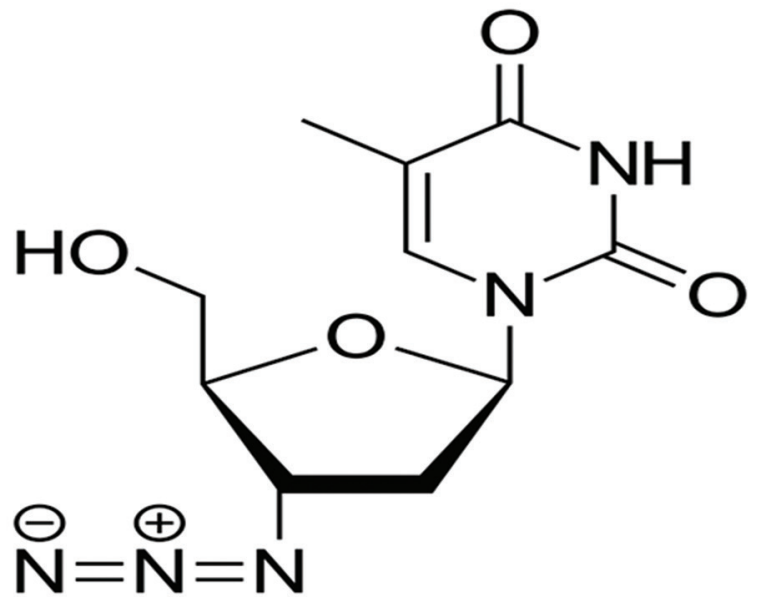

Fig. 2: Chemical structure of zidovudine

Table 1: Results for system suitability parameters

\begin{tabular}{lll}
\hline Parameter & $\begin{array}{l}\text { Lamivudine } \\
\text { (Average } \pm \text { SD) }\end{array}$ & $\begin{array}{l}\text { Zidovudine } \\
\text { (Average } \pm S D \text { ) }\end{array}$ \\
\hline Retention time $(\min )(\mathrm{n}=3)$ & $3.007 \pm 0.040$ & $4.660 \pm 0.073$ \\
Theoretical plate $(\mathrm{n}=3)$ & $4395 \pm 78.234$ & $4427 \pm 76.567$ \\
Asymmetry $(\mathrm{n}=3)$ & $1.17 \pm 0.15$ & $1.10 \pm 0.012$ \\
Resolution $(\mathrm{n}=3)$ & $7.18 \pm 0.337$ & \\
\hline
\end{tabular}

blank and standard preparations. Chromatograms were recorded and retention times from sample and standard preparations were compared for the identification of analytes.

\section{Linearity and range}

A series of standard solutions 5-15 $\mu \mathrm{g} / \mathrm{ml}$ of lamivudine and $15-35 \mu \mathrm{g} / \mathrm{ml}$ of zidovudine were prepared. An aliquot of $20 \mu \mathrm{l}$ of each solution was injected 3 times for each standard solutions and peak area was observed. Plot of average peak area versus the concentration is plotted and from this, the correlation coefficient and regression equation were generated. The calibration data of lamivudine and zidovudine are given in Table $2 \mathrm{a}$ and $\mathrm{b}$, while Fig. $3 \mathrm{a}$ and $\mathrm{b}$ represents linearity graphs of three drugs, respectively.

\section{Precision}

The method was validated in terms of intraday and interday precision. The solution containing lamivudine - $10 \mu \mathrm{g} / \mathrm{ml}$ and zidovudine $25 \mu \mathrm{g} / \mathrm{ml}$ was injected 6 times for repeatability study. Interday and intraday study was performed by injecting 5,10 , and $15 \mu \mathrm{g} / \mathrm{ml}$ of lamivudine and 15,25 , and $35 \mu \mathrm{g} / \mathrm{ml}$ of zidovudine solutions 3 times for each aliquot. The $\%$ RSD for precision study was found to be $<2 \%$, as shown in Table 3a-c.

\section{Accuracy}

Accuracy was determined by calculating recovery of lamivudine and zidovudine by the standard addition method. Known amounts of standard solutions of lamivudine $(5,10$, and $15 \mu \mathrm{g} / \mathrm{ml})$ and zidovudine $(15,25$, and $35 \mu \mathrm{g} / \mathrm{ml})$ were added to a pre-quantified test solutions

Table 2a: Linearity study lamivudine

\begin{tabular}{llllll}
\hline S. No. & \multicolumn{3}{l}{ Lamivudine } & \\
\cline { 2 - 3 } & \multicolumn{1}{l}{ Conc. $\mathbf{i n}$} & & Average & SD & RSD \\
\cline { 2 - 3 } \cline { 5 - 6 } & $\boldsymbol{\mu g} / \mathbf{m l}$ & & area $(\mathbf{n}=\mathbf{3})$ & & \\
\hline 1 & 5 & $1,425,631$ & 5765.35264 & 0.374352 \\
2 & 7.5 & $2,013,254$ & 7273.82154 & 0.312863 \\
3 & 10 & $2,523,568$ & $13,758.416$ & 0.508546 \\
4 & 12.5 & $3,253,647$ & $98,251.2259$ & 0.308521 \\
5 & 15 & $3,752,136$ & 8185.74361 & 0.22536 \\
\hline
\end{tabular}

Table 2b: Linearity study zidovudine

\begin{tabular}{|c|c|c|c|c|}
\hline \multirow[t]{3}{*}{ S. No. } & \multicolumn{4}{|c|}{ Zidovudine } \\
\hline & Conc. in & Average & SD & RSD \\
\hline & $\mu \mathrm{g} / \mathrm{ml}$ & area $(n=3)$ & & \\
\hline 1 & 15 & $7,012,583$ & $21,451.01$ & 0.308258 \\
\hline 2 & 20 & $9,154,236$ & $46,213.14$ & 0.421586 \\
\hline 3 & 25 & $10,826,086$ & $21,239.24$ & 0.112569 \\
\hline 4 & 30 & $12,958,902$ & $28,512.21$ & 0.201258 \\
\hline 5 & 35 & $15,782,169$ & $51,452.42$ & 0.325896 \\
\hline
\end{tabular}

Table 3a: Repeatability data for lamivudine and zidovudine

\begin{tabular}{lllll}
\hline Lamivudine & & & Zidovudine \\
\cline { 1 - 2 } \cline { 5 - 5 } $\begin{array}{l}\text { Concentration } \\
(\boldsymbol{\mu g} / \mathbf{m l})\end{array}$ & Area & & $\begin{array}{l}\text { Concentration } \\
(\boldsymbol{\mu g} / \mathbf{m l})\end{array}$ & Area \\
\hline 10 & & 25 & $10,666,320$ \\
10 & $2,568,124$ & & 25 & $10,661,582$ \\
10 & $2,554,452$ & & 25 & $10,624,256$ \\
10 & $2,582,441$ & & 25 & $10,682,784$ \\
10 & $2,574,532$ & & 25 & $10,654,321$ \\
10 & $2,578,486$ & & 25 & $10,697,869$ \\
Mean & $2,573,236$ & & Mean & $10,662,356$ \\
SD & $10,060.23$ & & SD & $22,310.272$ \\
RSD & 0.355256 & & RSD & 0.2022413 \\
\hline
\end{tabular}


of lamivudine $(10 \mu \mathrm{g} / \mathrm{ml})$ and zidovudine $(25 \mu \mathrm{g} / \mathrm{ml})$. Each solution was injected in triplicate and the recovery was calculated by measuring peak areas. Results obtained are shown in Table 4a and b.

Limit of detection (LOD) and limit of quantification (LOQ)

LOD and LOQ for SC and EV were calculated as suggested by ICH guidelines using equations $\mathrm{LOD}=3.3 \sigma / \mathrm{s}$ and $\mathrm{LOQ}=10 \sigma / \mathrm{s}$, respectively. Where, $\sigma$ is the $\mathrm{SD}$ of the response and $\mathrm{S}$ is the slope of the calibration curve.

\section{Robustness}

The robustness study was performed to evaluate the influence of small but deliberate variation in the chromatographic condition. The robustness was checked by making two small changes. The mobile ration was changed by $\pm 2 \mathrm{ml}$ and flow rate was changed by $\pm 0.02 \mathrm{ml} / \mathrm{min}$ and $\mathrm{pH}$ was changed by \pm 0.2 . After each changes, sample solution was injected and system suitability parameters were observed. The results are shown in Table 5

\section{RESULTS AND DISCUSSION}

System suitability study

The detection was carried out in the ultraviolet region at $272 \mathrm{~nm}$. The different composition of mobile phase was testing and the composition giving retention time of $3.007 \mathrm{~min}$ for lamivudine and $4.660 \mathrm{~min}$ for zidovudine with good resolution and theoretical plates was selected that optimized mobile phase was water: methanol $(65: 35 \mathrm{v} / \mathrm{v})$. A chromatogram of the mixture in optimized conditions is shown in Fig. 4 and the system suitability parameters are shown in Table 1.

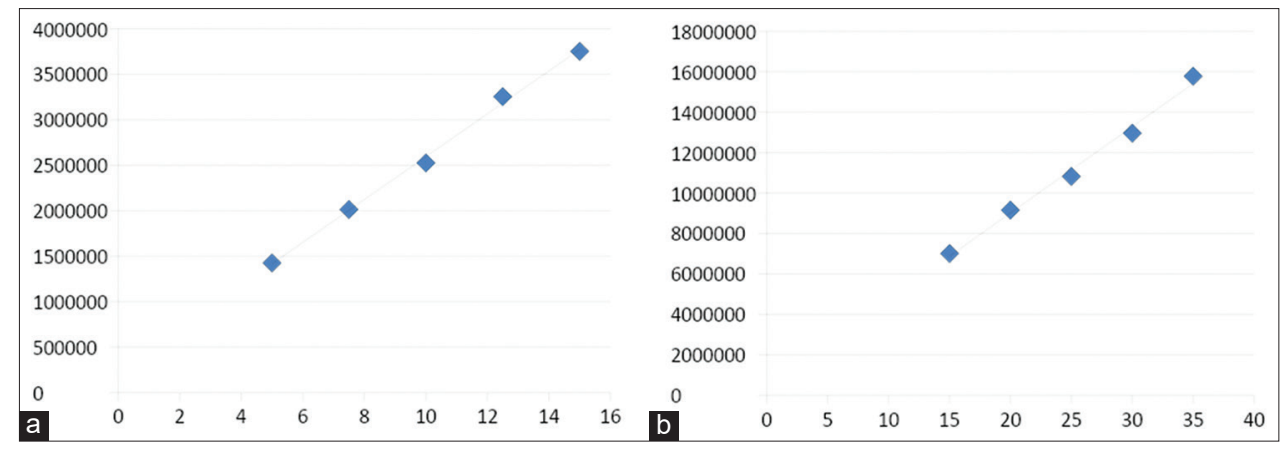

Fig. 3: (a) Linearity graph for lamivudine. (b) Linearity graph for zidovudine

Table 3b: Intraday data for lamivudine and zidovudine

\begin{tabular}{|c|c|c|c|c|c|}
\hline \multicolumn{3}{|c|}{ Lamivudine } & \multicolumn{3}{|c|}{ Zidovudine } \\
\hline Conc. & Area mean $\pm S D$ & $\%$ RSD & Conc. & Area mean $\pm S D$ & $\%$ RSD \\
\hline$(\mu \mathrm{g} / \mathrm{mL})$ & $(n=3)$ & & $(\mu \mathrm{g} / \mathrm{mL})$ & $(n=3)$ & \\
\hline 5 & $2,123,615.2 \pm 11,616.02$ & 0.54422 & 15 & $95,002,431 \pm 364,628.5$ & 0.374721 \\
\hline 10 & $2,676,544 \pm 12,445.54$ & 0.57443 & 25 & $10,231,574 \pm 57,091.72$ & 0.479944 \\
\hline 15 & $3,244,259.7 \pm 21,523.22$ & 0.61427 & 35 & $13,258,586 \pm 74,249.93$ & 0.54263 \\
\hline
\end{tabular}

Table 3c: Interday data for lamivudine and zidovudine

\begin{tabular}{|c|c|c|c|c|c|}
\hline \multicolumn{3}{|l|}{ Lamivudine } & \multicolumn{3}{|l|}{ Zidovudine } \\
\hline Conc. $(\mu \mathrm{g} / \mathrm{mL})$ & Area mean $\pm \operatorname{SD}(n=3)$ & $\%$ RSD & Conc. $(\mu \mathrm{g} / \mathrm{mL})$ & Area mean $\pm \operatorname{SD}(n=3)$ & $\%$ RSD \\
\hline 5 & $2,114,251.4 \pm 4467.526$ & 0.205896 & 15 & $95,235,896 \pm 18,619.11$ & 0.011258 \\
\hline 10 & $2,652,866.1 \pm 14,123.45$ & 0.524021 & 25 & $10,251,342 \pm 95,642.44$ & 0.802413 \\
\hline 15 & $3,243,725.2 \pm 21,268.14$ & 0.605823 & 35 & $13,421,842 \pm 50,241.14$ & 0.351242 \\
\hline
\end{tabular}

Table 4a: The accuracy study results of lamivudine

\begin{tabular}{|c|c|c|c|c|c|}
\hline $\begin{array}{l}\% \text { accuracy } \\
\text { level }\end{array}$ & $\begin{array}{l}\text { Amount of lamivudine } \\
\text { taken }(\mu \mathrm{g} / \mathrm{ml})\end{array}$ & $\begin{array}{l}\text { Amount of standard } \\
\text { lamivudine added }(\mu \mathrm{g} / \mathrm{ml})\end{array}$ & $\begin{array}{l}\text { Total amount of } \\
\text { lamivudine }(\mu \mathrm{g} / \mathrm{ml})\end{array}$ & $\begin{array}{l}\text { Amount of lamivudine } \\
\text { found }(\mu \mathrm{g} / \mathrm{ml}) \pm S D(n=3)\end{array}$ & $\begin{array}{l}\text { Mean \% recovered } \pm \\
\text { SD }(n=3)\end{array}$ \\
\hline 50 & 10 & 5 & 15 & $15.20 \pm 0.05$ & $99.82 \pm 0.11$ \\
\hline 100 & 10 & 10 & 20 & $19.98 \pm 0.10$ & $99.75 \pm 0.21$ \\
\hline 150 & 10 & 15 & 25 & $24.95 \pm 0.04$ & $99.72 \pm 0.19$ \\
\hline
\end{tabular}

Table 4b: The accuracy study results of zidovudine

\begin{tabular}{|c|c|c|c|c|c|}
\hline $\begin{array}{l}\% \text { accuracy } \\
\text { level }\end{array}$ & $\begin{array}{l}\text { Amount of zidovudine } \\
\text { taken }(\mu \mathrm{g} / \mathrm{ml})\end{array}$ & $\begin{array}{l}\text { Amount of standard } \\
\text { zidovudine added }(\mu \mathrm{g} / \mathrm{ml})\end{array}$ & $\begin{array}{l}\text { Total amount of } \\
\text { zidovudine }(\mu \mathrm{g} / \mathrm{ml})\end{array}$ & $\begin{array}{l}\text { Amount of zidovudine } \\
\text { found }(\mu \mathrm{g} / \mathrm{ml}) \pm S D(n=3)\end{array}$ & $\begin{array}{l}\text { Mean \% recovered } \pm S D \\
(n=3)\end{array}$ \\
\hline 50 & 25 & 12.5 & 37.5 & $37.21 \pm 0.10$ & $99.74 \pm 0.10$ \\
\hline 100 & 25 & 25 & 50 & $50.17 \pm 0.20$ & $99.71 \pm 0.20$ \\
\hline 150 & 25 & 37.5 & 62.5 & $62.16 \pm 0.11$ & $99.68 \pm 0.19$ \\
\hline
\end{tabular}




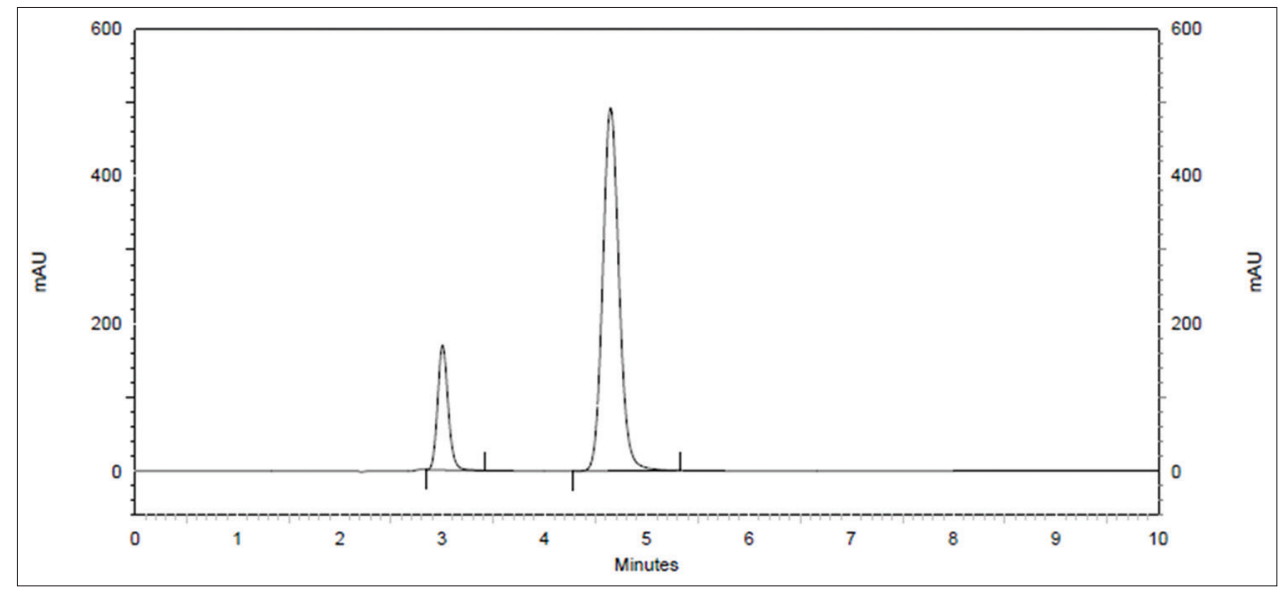

Fig. 4: Optimized condition chromatogram of lamivudine and zidovudine

Table 5: Robustness study results for lamivudine and zidovudine

\begin{tabular}{|c|c|c|c|}
\hline \multirow[t]{2}{*}{ Parameter } & & \multicolumn{2}{|l|}{ Area $(n=3)$} \\
\hline & & Lamivudine & Zidovudine \\
\hline & $0.78 \mathrm{ml}$ & $2,631,115.31$ & $11,491,258$ \\
\hline & $0.82 \mathrm{ml}$ & $2,605,215$ & $10,256,893$ \\
\hline \multirow[t]{3}{*}{ Flow rate $( \pm 0.02 \mathrm{ml} / \mathrm{min})$} & Mean \pm SD & $2,624,795.448 \pm 15,512.54809$ & $10,963,525 \pm 95,586.412$ \\
\hline & $\%$ RSD & 0.60152368 & 0.8100642 \\
\hline & $63: 37 \%$ & $2,635,569.67$ & $10,934,223$ \\
\hline \multirow[t]{2}{*}{ Mobile phase composition } & $65: 35 \%$ & $2,624,163$ & $10,904,136$ \\
\hline & $67: 33 \%$ & $2,598,010.67$ & $10,959,475$ \\
\hline \multirow[t]{5}{*}{ Water:methanol $( \pm 2 \mathrm{ml})$} & Mean \pm SD & $2,619,247.778 \pm 18,233.88682$ & $10,931,277 \pm 28,780.471$ \\
\hline & $\%$ RSD & 0.608132851 & 0.2396 \\
\hline & 270 & $2,635,584.33$ & $10,934,112$ \\
\hline & 272 & $2,624,130$ & $10,913,467$ \\
\hline & 274 & $2,598,010.67$ & $11,125,675$ \\
\hline \multirow[t]{2}{*}{ Wavelength $( \pm 2 \mathrm{~nm})$} & Mean \pm SD & $2,619,241.667 \pm 18,257.9064$ & $10,991,085 \pm 107,015.14$ \\
\hline & $\%$ RSD & 0.698208712 & 0.8458512 \\
\hline
\end{tabular}

\section{Method validation}

Specificity

The method was found to be specific as there was no interference observed in any of the parameters under observation.

\section{Linearity and range}

The linearity of lamivudine and zidovudine was found between $5-15 \mu \mathrm{g} / \mathrm{ml}$ and $15-35 \mu \mathrm{g} / \mathrm{ml}$, respectively. The results are shown in Table $2 \mathrm{a}$ and $\mathrm{b}$.

\section{Precision}

The \%RSD for repeatability study for lamivudine and zidovudine was found to be 0.355 and 0.202 , respectively. The interday and intraday study also shows \%RSD value for lamivudine and zidovudine within the acceptable limit. Results for precision study are shown in Table 3a-c.

\section{Accuracy}

Accuracy of the method was confirmed by recovery study at three levels $(50 \%, 100 \%$, and $150 \%)$ of standard addition. Percentage recovery for lamivudine was found to be $99.72-99.82 \%$ and zidovudine was found to be $99.68-99.74 \%$, as shown in Table $4 \mathrm{a}$ and $\mathrm{b}$.

\section{LOD and LOQ}

The LOD was found to be $0.285 \mu \mathrm{g} / \mathrm{ml}$ for lamivudine and $0.225 \mu \mathrm{g} / \mathrm{ml}$ for zidovudine, while the LOQ was found to be $0.889 \mu \mathrm{g} / \mathrm{ml}$ for lamivudine and $0.723 \mu \mathrm{g} / \mathrm{ml}$ for zidovudine.

\section{Robustness}

The typical variations studied under this parameter were mobile phase composition, $\mathrm{pH}$, and flow rate. Overall $\% \mathrm{RSD}$ was found to be $<2 \%$ for all the variations which indicates that the proposed method is robust. Robustness data are shown in Table 5.

\section{Analysis of marketed formulation by proposed method}

Applicability of the proposed method was tested by analyzing the commercially available marketed formulation. The percentage of lamivudine and zidovudine was found to be $100.02 \%$ for lamivudine and $99.86 \%$ for zidovudine, respectively.

\section{CONCLUSION}

From the above discussion, it can be concluded that the proposed method is specific, precise, and accurate. Results are in good agreement with label claim which indicates that there is no interference of excipients. Therefore, the proposed method can be used for routine analysis of lamivudine and zidovudine in combined tablet formulation.

\section{ACKNOWLEDGMENT}

The authors are also thankful to Saraswati Institute of Pharmaceutical Sciences for providing necessary equipment, facility, and chemicals to complete research work and sincere thanks to my highly respected and esteemed, Principal, Dr. Shrenik Shah, Director and HOD of PG Department Dr. Ankit B Chaudhary. I would like to express thanks to my parents without their encouragement love and blessings I would not have reached this level manuscript. 


\section{REFERENCES}

1. Indian Pharmacopoeia. The Indian Pharmacopoeia Commission. Vol. 2. Ghaziabad: Indian Pharmacopoeia; 2014. p. 2054-65.

2. Available from:https://www.pubchem.ncbi.nlm.nih.gov/compound/ lamivudine\#section=chemical-and-physical-properties. [Last accessed on $2020 \mathrm{Jan}$ ]

3. British Pharmacopeia. British Pharmacopeia Commission Office. London: British Pharmacopeia; 2010. p. 1241-3.

4. Kumar DA, Naveenbabu MV, Seshagirirao JV, Jayatirtharao V. Simultaneous determination of lamivudine, zidovudine and nevirapine in tablet dosage form by RP-HPLC Method. Rasayan J Chem 2010;3:94-9.

5. Raja T, Lakshamana A. Development and validation of RP-HPLC method for estimation of abacavir, lamivudine and zidovudine in pharmaceutical dosage form. Int J PharmTech Res 2011;3:852-7.

6. The United States Pharmacopoeial Convention. The United State Pharmacopoeia: UPS 31, The National Formulary: NF 26. Vol. 2. Rockville, MD: The United States Pharmacopoeial Convention; 2008. p. 2498-9.

7. Available from: https://www.pubchem.ncbi.nlm.nih.gov/compound/ 35370. [Last accessed on 2020 Jan ???].
8. Indian Pharmacopoeia. The Indian Pharmacopoeia Commission. Vol. 3. Ghaziabad: Indian Pharmacopoeia; 2014. p. 3003-9.

9. The United States Pharmacopoeial Convention. The United State Pharmacopoeia: UPS 31; The National Formulary: NF 26. Vol. 3. Rockville, MD: The United States Pharmacopoeial Convention; 2008. p. 3539-41.

10. Dos Santos JV, de Carvahlo LA. Development and validation of a RP-HPLC method for the determination of zidovudine and its related substances in sustained-release tablets. Anal Sci 2011;27:283-90.

11. Padmaja M, Prashanth KN, Suresha JN. RP-HPLC method development and validation for simultaneous estimation of efavirenze, lamivudine and zidovudine in tablet dosage form. J Bio Innov 2017;6:286-305.

12. FDA. Guidance for Industry; Analytical Procedures and Methods Validation (Draft guidance), Food and Drug administration. Rockville: US Department of Health and Human Services, FDA; 2000.

13. Kamala GR, Vadrevu S, Valli KN. Development and validation of RP-HPLC method for simultaneous estimation of lamivudine and zidovudine in bulk. Int J Curr Pharm Res 2016;8:28-33.

14. Juluri KD, Rajan RG. RP-HPLC method developmemt and validation for simultaneous estimation and forced degradation studies of lamivudine and raltegravir in solid dosage form. Int J Appl Pharm 2018;10:242-8. 